\title{
Synthesis and X-Ray Crystal Structures of Tetranuclear
}

\section{Zincamidinate Complexes}

Benjamin Gutschank, Stephan Schulz, * Ulrich Westphal, Dieter Bläser, Roland Boese

Institute of Inorganic Chemistry, University of Duisburg-Essen, 45117 Essen, Germany.

E-mail: stephan.schulz@uni-due.de

RECEIVED DATE (to be automatically inserted after your manuscript is accepted if required according to the journal that you are submitting your paper to)

* To whom correspondence should be addressed. Prof. Dr. Stephan Schulz, Institute of Inorganic Chemistry, University of Duisburg-Essen, S07 S03 C30, 45117 Essen, Germany; Phone: +49 02011834635; Fax: + 49 0201-1833830; e-mail: stephan.schulz@uni-due.de.

Summary: Polynuclear amidinate zinc halide complexes of the general type $\left\{\mathrm{C}\left[\mathrm{C}(\mathrm{N} i \text {-Pr })_{2} \mathrm{ZnX}\right]_{4}\right\}[\mathrm{X}=$ $\mathrm{Cl} 2, \mathrm{Br} 3, \mathrm{I} 4]$ were prepared in high yields via methyl/halide exchange reaction of $\{\mathrm{C}[\mathrm{C}(\mathrm{N} i$ Pr) $\left.\left.{ }_{2} \mathrm{ZnMe}\right]_{4}\right\}$ 1a with $\mathrm{AlX}_{3} .2$ - 4 were characterized by elemental analysis, multinuclear NMR and IR spectroscopy and single crystal X-ray diffraction. Computational calculations of halide-substituted complexes $\left\{\mathrm{C}\left[\mathrm{C}(\mathrm{N} i \text {-Pr })_{2} \mathrm{ZnX}\right]_{4}\right\}[\mathrm{X}=\mathrm{F}-\mathrm{I}]$ were performed to clarify the influence of the halide atom on the structural parameters of the complexes and to elucidate their electronic structure and bonding situation. The capability of these halide-substituted complexes to serve as suitable starting reagent for further salt elimination reactions was proven by reaction of 2 with $\mathrm{LiR}(\mathrm{R}=\mathrm{Me}, n-\mathrm{Bu})$ and $\mathrm{EtMgBr}$, which yielded the corresponding Zn-Alkyl species $\left\{\mathrm{C}\left[\mathrm{C}(\mathrm{N} i-\mathrm{Pr})_{2} \mathrm{ZnR}\right]_{4}\right\}[\mathrm{R}=\mathrm{Me} \mathrm{1b}, n-\mathrm{Bu} \mathbf{5}$, Et 6]. 
Introduction. Anionic $\mathrm{N}, \mathrm{N}^{\prime}$-chelating ligands such as $\beta$-diketiminate ${ }^{1}$, amidinate and guanidinate ${ }^{2-4}$ have a remarkable ability to form a variety of molecular rearrangements. They were found to bind to metal centers either as monodentate two-electron donor $\left(\eta^{1}\right)$, chelating $\left(\eta^{2}\right)$ or bridging monodentate $(\mu$ $\eta^{1}-\eta^{1}$ ) four-electron donor. ${ }^{5}$ Furthermore their steric and electronic properties can easily be tuned by variation of the organic substituents, which makes them very useful in the synthesis of tailor-made complexes for catalysis, material science and organic-inorganic hybrid materials. ${ }^{6,7}$ Moreover, they have been used as stabilizing ligands in the synthesis of cluster-type complexes such as an imidosamariumheterocubane, a tetranuclear $\mathrm{Au}(\mathrm{I})$-amidinate complex as well as several di- and tetranuclear $\mathrm{Cu}$ complexes (Scheme 1). ${ }^{8-10}$ Multinuclear metal complexes generally have received a growing interest in recent years in the field of catalysis ${ }^{11}$, as single source precursors for CVD applications ${ }^{12}$ and as model complexes for metalloenzymes in biochemistry. ${ }^{13}$

\section{Scheme 1 here}
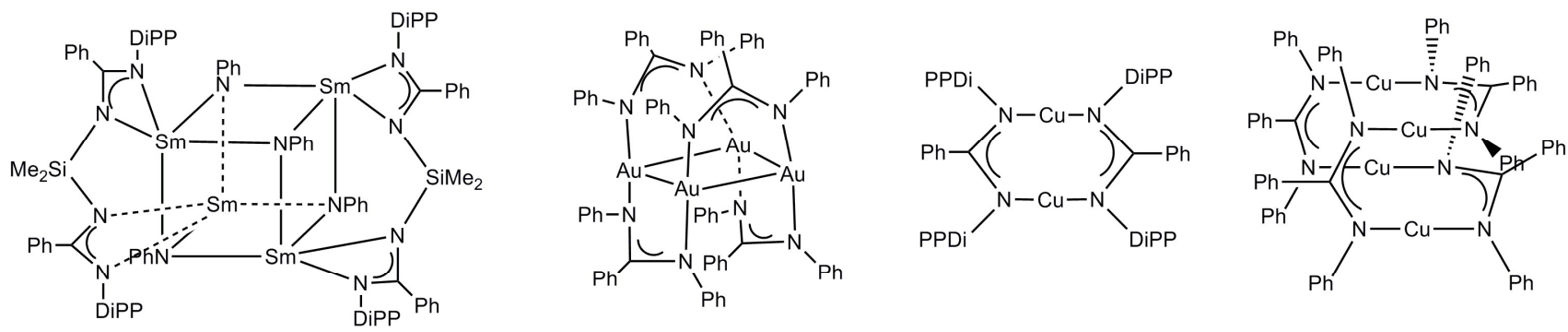

$\mathrm{Ph}=$ Phenyl; DiPP = 2,6 Diisopropylphenyl

Very recently, we reported on reactions of carbodiimides $\mathrm{C}(\mathrm{NR})_{2}(\mathrm{R}=i-\mathrm{Pr}, \mathrm{Cy})$ with dimethylzinc at elevated temperatures, resulting in the formation of tetranuclear zinc amidinate complexes such as $\left\{\mathrm{C}\left[\mathrm{C}(\mathrm{NR})_{2} \mathrm{ZnMe}\right]_{4}\right\}(\mathrm{R}=i$-Pr 1a, Cy $\mathbf{1 b})$ via an insertion/deprotonation mechanism. ${ }^{14,15}$ The zinc atoms in $1 \mathbf{a}$ and $\mathbf{1 b}$ are rather located at the circumference of the cluster whereas the metal atoms in complexes as shown in Scheme 1 rather build the cluster core, which is completely shielded by the organic substituents. As a consequence, the zinc centers in $\mathbf{1 a}$ and $\mathbf{1 b}$ are more easily accessible and the complexes are expected to be suitable starting reagents for further substitution reactions. However, initial studies on reactions of $\mathbf{1 a}$ with $\mathrm{H}$-acidic compounds such as amines $\mathrm{RNH}_{2}$, alcohols $\mathrm{ROH}$ and 
even water failed to give the expected methane-elimination products, clearly demonstrating that the $\mathrm{Zn}$ Me group is rather less reactive. ${ }^{16}$ Consequently, we became interested in synthesis of the corresponding halide-substituted complexes, which were expected to be more reactive. Herein we report on the complexes of the general type $\left\{\mathrm{C}\left[\mathrm{C}(\mathrm{Ni}-\mathrm{Pr})_{2} \mathrm{ZnX}\right]_{4}\right\}(\mathrm{X}=\mathrm{Cl} \mathbf{2}, \mathrm{Br} \mathbf{3}, \mathrm{I}$ 4), which were prepared in high (2 - 3) to moderate yields (4) by $\mathrm{Me} /$ halide exchange reaction of in 1a with $\mathrm{AlX}_{3}(\mathrm{X}=\mathrm{Cl}, \mathrm{Br}, \mathrm{I})$. Moreover, initial studies on the reaction of 2 with $\mathrm{MeLi}, n-\mathrm{BuLi}, t$-BuLi and EtMgBr are presented.

\section{Results and Discussion.}

Solutions of $1 \mathrm{a}$ with four equivalents of $\mathrm{AlX}_{3}(\mathrm{X}=\mathrm{Cl}, \mathrm{Br}, \mathrm{I})$ in $\mathrm{Et}_{2} \mathrm{O}$ were stirred at $40{ }^{\circ} \mathrm{C}$ for 2 hours, yielding the corresponding halide-substituted complexes $\mathbf{2}-\mathbf{4}$. Colorless crystalline solids of $\mathbf{2}-\mathbf{4}$ were obtained from solutions in toluene at $-30{ }^{\circ} \mathrm{C}$.

\section{Scheme 2 here}

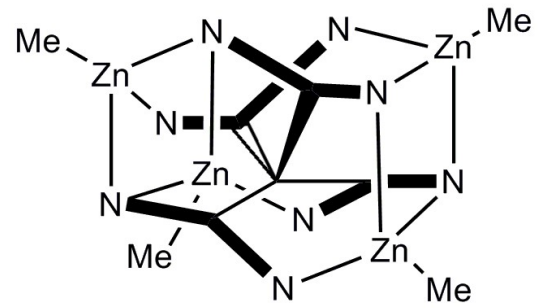

1a
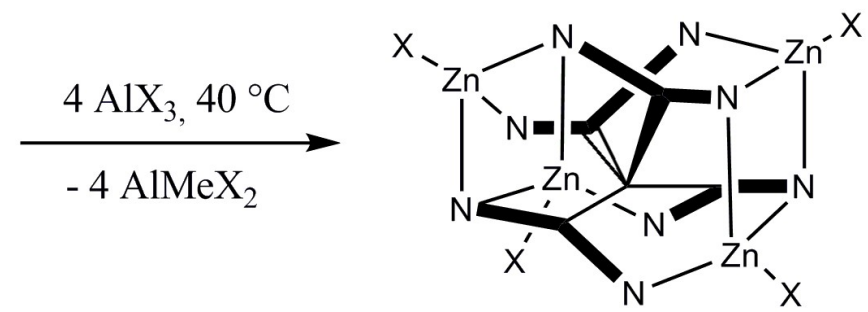

$\mathrm{X}=\mathrm{Cl}$ 2, $\mathrm{Br} 3, \mathrm{I} 4$

\section{Figure 1 here}

\section{Table 1 here}

${ }^{1} \mathrm{H}$ NMR spectra of the bulk reaction mixtures of $\mathbf{2}-\mathbf{4}$ showed characteristic resonances of two nonequivalent $i$-Pr groups as was observed for the methyl-substituted complex 1a. Both the doublet and the septet of $\mathbf{2}-\mathbf{4}$ are shifted to lower field compared to 1a, with the degree of shift extension increasing with decreasing electronegativity of the halide substituent. The missing Zn-Me resonance and the formation of typical singlets for $\mathrm{MeAlX}_{2}$ in NMR tube reactions indicate the Me/halide exchange reaction. The characterization of $\mathbf{4}$ in solution by NMR spectroscopy turned out to be problematical due to its limited solubility in the applied solvents $\left(\mathrm{C}_{6} \mathrm{D}_{6}, \mathrm{THF}-\mathrm{d}_{8}\right)$ and its strong tendency to decompose at 
temperatures above $40{ }^{\circ} \mathrm{C}$. As a consequence, ${ }^{1} \mathrm{H}$ NMR spectra of 4 in different solvents showed additional resonances, which overlap the typical resonances of the $i$-Pr groups. However, comparative ${ }^{13} \mathrm{C}$ CPMAS NMR studies of complexes 2 and $\mathbf{4}$ clearly revealed the structural analogy of both complexes. ${ }^{17}$ Both spectra show two signals around 24 and $50 \mathrm{ppm}$ of the $i$-Pr groups, whereas the carbon atoms of the amidinate unit $\left(\mathrm{CN}_{2}\right.$ unit) show a sharp signal at $169 \mathrm{ppm}$. The central $\mathrm{sp}^{3}-$ hybridized carbon atoms in $\mathbf{2}$ and $\mathbf{4}$ show a very weak resonance at about $70 \mathrm{ppm}$ due to the almost ideal tetrahedral coordination of four amidinate groups, which leads to an elongated spin relaxation time and thus to magnetic saturation at rather short relaxation delay times.

\section{Figure 2 here}

\section{Table 2 here}

Colorless crystals of $2-4$ were obtained from solutions in toluene after storage for $24 \mathrm{~h}$ at $-30{ }^{\circ} \mathrm{C}$ (Figures 2 - 4). 2 and 3 are isostructural and crystallize in the trigonal space group $P 3_{1} 21$, whereas complex 4 crystallizes in the trigonal space group $P 3_{2} 21$. All structures contain additional disordered toluene molecules in their crystal lattice. The cluster core as was observed in $\mathbf{1 a}$ is still preserved in $\mathbf{2}-$ $\mathbf{4}$ and the central structural parameters are almost unchanged. The general structural motif of $\mathbf{2}-\mathbf{4}$ is the central $\mathrm{sp}^{3}$-hybridized $\mathrm{C}_{\text {center }}$ atom, which is tetrahedrally coordinated by four $\mathrm{C}$ atoms of adjacent amidinate groups. The C-C bond lengths are in the range of typical C-C single bonds (2: 1.563(3) 1.569(3), 3: 1.563(4) - 1.565(4), 4: 1.567(5) - 1.589(5) $\AA$ ). The N-C bond lenghts within the amidinate groups indicate a delocalized $\pi$-electron system (average values: $21.331 \AA, 31.332 \AA, 41.329 \AA$ ) as was found in $\mathbf{1 a}(\varnothing 1.334 \AA$ ). The $\mathrm{Zn}$ atoms within $\mathbf{2}-\mathbf{4}$ are coordinated by three $\mathrm{N}$ atoms of adjacent amidinate groups with almost identical Zn-N bond lengths of 2.093(2) - 2.142(2) $\AA$ (2), 2.090(3)2.145(3) $\AA$ (3) and 2.099(4)-2.157(4) $\AA$ (4), respectively. Obviously, the ligand geometrie is hardly affected by the different halide atoms. The only structural differences within $\mathbf{2}-\mathbf{4}$ are reflected by the Zn-X bond lengths, which increase from chlorine to iodine (average values: 2 2.172 $\AA$ ), $32.307 \AA, 4$ $2.503 \AA$ ) as was expected from ascending ionic radii of the halide substituents.

Table 3 here 
Theoretical calculations of the halide-substituted complexes $\left\{\mathrm{C}\left[\mathrm{C}(\mathrm{N} i-\mathrm{Pr})_{2} \mathrm{ZnX}\right]_{4}\right\}\left(\mathrm{X}=\mathrm{F} \mathbf{5}^{\prime}, \mathrm{Cl} \mathbf{2}^{\prime}, \mathrm{Br}\right.$ 3', I 4')were performed to elucidate the influence of the halide atoms on the structural parameters of the complexes and their electronic structure, in particular the M-N bonding character. NBO analysis clearly prove an increasing trend of negative charge at the halide atoms and positive charge on the metal centers from iodine to fluorine substituted complexes (Table 3) as was expected due to the different electronegativities and electron withdrawing effects of the halide atoms. The charges within the chelating amidinate moiety remain almost unchanged. As a consequence, the ionic character of the $\mathrm{Zn}$ $\mathrm{N}$ bonding increases from the iodine to the fluorine compound. The structural parameters of the calculated complexes (Table 4) such as $\mathrm{C}-\mathrm{C}$ and $\mathrm{Zn}-\mathrm{N}$ bond distances as well as N-C-N bond angles are very similar and in good agreement with the experimentally determined values.

\section{Table 4 here}

In order to prove the general capability of the halide-substituted complexes to serve as starting reagent for further salt elimination reactions, 2 was reacted with several organolithium and -magnesium compounds. The reaction of 2 with $\mathrm{MeLi}$ and $n$-BuLi as well as EtMgBr yielded the expected alkylsubstituted complexes $\left\{\mathrm{C}\left[\mathrm{C}(\mathrm{N} i-\mathrm{Pr})_{2} \mathrm{ZnR}\right]_{4}\right\}(\mathrm{R}=\mathrm{Me}$ 1a, $n$-Bu 5, Et 6), respectively. In contrast, the reaction with $t$-BuLi occurred with decomposition of 2 and formation of a dark-grey solid (Zn). NMR experiments clearly showed the formation of iso-butene during this reaction, which points to a $\beta$ hydride elimination reaction. However, the zinc hydride complex $\left\{\mathrm{C}\left[\mathrm{C}(\mathrm{N} i-\mathrm{Pr})_{2} \mathrm{ZnH}\right]_{4}\right\}$ couldn't be isolated.

\section{Scheme 3 here}

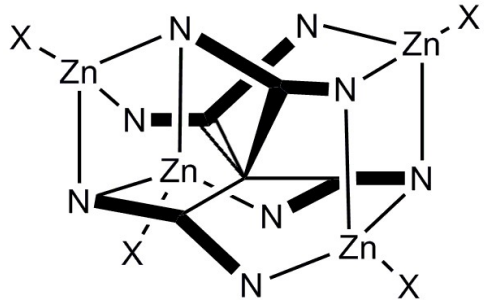

2

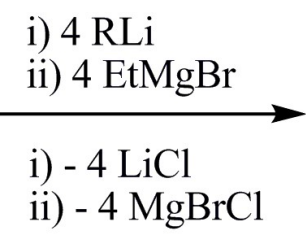

ii) $-4 \mathrm{MgBrCl}$

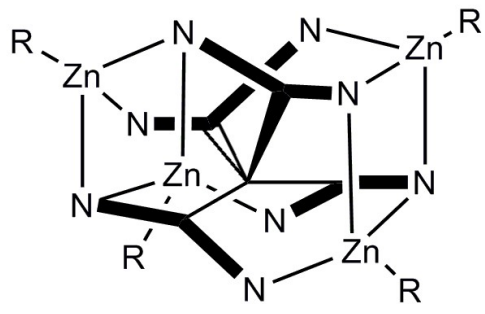

$\mathrm{R}=\mathrm{Me} \mathbf{1 a}, n-\mathrm{Bu} \mathbf{5}$, Et $\mathbf{6}$ 
1a, 5 and 6 were isolated as colorless crystalline solids and characterized by ${ }^{1} \mathrm{H}$ and ${ }^{13} \mathrm{C}$ NMR spectroscopy. The resonances of the $i$-Pr groups in the ${ }^{1} \mathrm{H}$ spectra of 5 and $\mathbf{6}$ at room temperature are broadened and the typical fine structure of the septets and doublets as was observed for $\mathbf{1 a}$ as well as $\mathbf{2}$ 4 couldn't be resolved. Temperature dependant dynamic NMR experiments in the temperature range of 30 to $100{ }^{\circ} \mathrm{C}$ in toluene- $\mathrm{d}_{8}$ demonstrate that the new complexes equilibrate between a "cage-type" and an "open-type" cluster depicted in scheme 4. The formation of both forms (constitutional isomerism) is strongly temperature-dependant and fully reversible. The equilibrium is shifted to the cage-type form at ambient temperature whereas the open form is preferred at higher temperature. The isomerization seems to be sterically induced by the substituents $(\mathrm{Et}, n$ - $\mathrm{Bu})$ because the Me substituted complex 1a didn't show this behavior at room temperature. The coalescence temperature for $5\left(50{ }^{\circ} \mathrm{C}\right)$ and $\mathbf{6}\left(64{ }^{\circ} \mathrm{C}\right)$, which were experimentally determined by NMR spectroscopy, decrease with increasing steric demand of the organic substituent.

\section{Scheme 4 here}

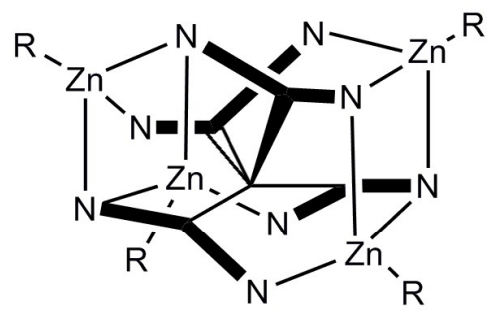

"cage-type" complex

$\mathrm{R}=\mathrm{Et}, n-\mathrm{Bu}$

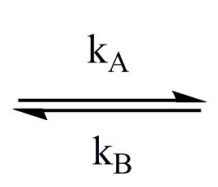

"open-type" complex

\section{Figure 3 here}

Conclusion. Halide-substituted zinc amidinate complexes $\mathbf{2}-\mathbf{4}$ are accessible be methyl/halide exchange reactions between 1a and aluminum halides. These complexes are suitable starting reagents for further salt elimination reactions. Initial studies on the reaction of 2 with $\mathrm{MeLi}, n$-BuLi and $\mathrm{EtMgBr}$ demonstrate the almost quantitative formation of the corresponding alkyl-substituted derivatives $\mathbf{1 a}, \mathbf{5}$, 
and 6. In contrast, the reaction with $t$-BuLi occurred with decomposition and formation of elemental zinc. Further reactions are currently under investigation.

Experimental Section. All manipulations were performed under an Ar atmosphere using standard Schlenk line technique. Solvents were carefully dried over $\mathrm{Na} / \mathrm{K}$ and degassed prior to use. $\mathrm{C}(\mathrm{N} i \text { - } \mathrm{Pr})_{2}$ was carefully dried over activated molecular sieves. A $1.2 \mathrm{M}$ solution of $\mathrm{ZnMe}_{2}$ in toluene was purchased from Acros and used as received. Aluminiumhalides were purified by sublimation prior to use. ${ }^{1} \mathrm{H}$ and ${ }^{13} \mathrm{C}$ NMR spectra were recorded on a Bruker DMX 300 spectrometer and are referenced to internal $\mathrm{C}_{6} \mathrm{D}_{5} \mathrm{H}\left({ }^{1} \mathrm{H}: \delta=7.154 ;{ }^{13} \mathrm{C}: \delta=128.0\right)$ or $\mathrm{C}_{7} \mathrm{D}_{8}\left({ }^{1} \mathrm{H}: \delta=2.03 ;{ }^{13} \mathrm{C}: \delta=137.5\right) .{ }^{13} \mathrm{C}$ CPMAS NMR spectra were recorded on a Bruker Avance 400 using a $4 \mathrm{~mm}$ MAS rotor head at $5 \mathrm{kHz}$ rotation and Hartmann-Hahn contact of $1 \mathrm{~ms}$. IR spectra were recorded on an ALPHA-T FT-IR spectrometer with a single reflection ATR sampling module. Melting points were measured in sealed capillaries and were not corrected. Elemental analyses were performed at the Elementaranalyse Labor of the University of Essen.

$\left\{\mathbf{C}\left[\mathbf{C}(\mathbf{N i}-\mathbf{P r})_{2} \mathbf{Z n C l}_{4}\right\}\right.$ 2. $0.21 \mathrm{~g}$ of $\mathbf{1}(0.25 \mathrm{mmol})$ and $0.14 \mathrm{~g}$ of $\mathrm{AlCl}_{3}(1 \mathrm{mmol})$ were dissolved in 15 $\mathrm{mL}$ of dichlormethane and stirred for $2 \mathrm{~h}$ under reflux. Thereafter, all volatiles were removed at reduced pressure. The resulting yellowish solid was dissolved in $15 \mathrm{~mL}$ of toluene, filtrated and stored at $-30{ }^{\circ} \mathrm{C}$ for $24 \mathrm{~h}$. Colorless crystals of 2 were formed within $24 \mathrm{~h}$ and isolated by filtration.

Yield (isolated crystals): $0.17 \mathrm{~g}$ (74\%). Melting point: $250{ }^{\circ} \mathrm{C}$ (decomposition). Anal. Found (calcd) for $\mathrm{C}_{29} \mathrm{H}_{56} \mathrm{~N}_{8} \mathrm{Zn}_{4} \mathrm{Cl}_{4}$ (920.26 g/mol): H, 6.09 (6.13); C, 37.47 (37.85); N, 11.98 (12.17). ${ }^{1} \mathrm{H}$ NMR (300 $\left.\mathrm{MHz}, \mathrm{C}_{6} \mathrm{D}_{6}, 25{ }^{\circ} \mathrm{C}\right): \delta 1.24\left(\mathrm{~d}, 24 \mathrm{H},{ }^{3} \mathrm{~J}_{\mathrm{HH}}=6.4 \mathrm{~Hz}, \mathrm{CH}\left(\mathrm{CH}_{3}\right)_{2}\right), 1.54\left(\mathrm{~d}, 24 \mathrm{H},{ }^{3} J_{H H}=6.4 \mathrm{~Hz}\right.$, $\left.\mathrm{CH}\left(\mathrm{CH}_{3}\right)_{2}\right), 3.68\left(\mathrm{sept}, 4 \mathrm{H},{ }^{3} J_{H H}=6.4 \mathrm{~Hz}, \mathrm{CH}\left(\mathrm{CH}_{3}\right)_{2}\right), 4.10$ (sept, $\left.4 \mathrm{H},{ }^{3} J_{H H}=6.4 \mathrm{~Hz}, \mathrm{CH}\left(\mathrm{CH}_{3}\right)_{2}\right) .{ }^{13} \mathrm{C}$ NMR $\left(200 \mathrm{MHz}, \mathrm{C}_{6} \mathrm{D}_{6}, 25{ }^{\circ} \mathrm{C}\right): \delta 23.5\left(\mathrm{CH}\left(\mathrm{CH}_{3}\right)_{2}\right), 24.4\left(\mathrm{CH}\left(\mathrm{CH}_{3}\right)_{2}\right), 48.8\left(\mathrm{CH}\left(\mathrm{CH}_{3}\right)_{2}\right), 50.6$ $\left(\mathrm{CH}\left(\mathrm{CH}_{3}\right)_{2}\right), 71.9(\mathrm{CC} 4), 169.6(\mathrm{NCN}) \cdot{ }^{13} \mathrm{C} \mathrm{CP}$ MAS NMR $\left(400 \mathrm{MHz}, 25{ }^{\circ} \mathrm{C}\right): \delta 22.3-26.0$ $\left(\mathrm{CH}\left(\mathrm{CH}_{3}\right)_{2}\right), 49.0\left(\mathrm{CH}\left(\mathrm{CH}_{3}\right)_{2}\right), 50.8\left(\mathrm{CH}\left(\mathrm{CH}_{3}\right)_{2}\right), 71.2\left(\mathrm{CC}_{4}\right), 169.8(\mathrm{NCN})$. ATR-IR: v 2966, 2934, $2905,2873,1560,1521,1453,1392,1371,1257,1243,1068,1014,868,793,661,543,526,472 \mathrm{~cm}^{-1}$. 
$\left\{\mathbf{C}\left[\mathbf{C}(\mathbf{N i}-\mathbf{P r})_{2} \mathbf{Z n B r}\right]_{4}\right\}, \mathbf{3} .0 .25 \mathrm{~g}$ of $\mathbf{1}(0.3 \mathrm{mmol})$ and $0.32 \mathrm{~g}$ of $\mathrm{AlBr}_{3}(1.2 \mathrm{mmol})$ were dissolved in 15 $\mathrm{mL}$ of toluene and stirred for $1 \mathrm{~h}$ at $60^{\circ} \mathrm{C}$. A small amount of a yellowish precipitate was formed, which was isolated by filtration. The filtrate was stored at $-30{ }^{\circ} \mathrm{C}$ for crystallization. Colorless crystals of $\mathbf{3}$ were formed within $24 \mathrm{~h}$ and isolated by filtration.

Yield (isolated crystals): $0.29 \mathrm{~g}$ (88\%). Melting point: $217^{\circ} \mathrm{C}$ (decomposition). Anal. Found (calcd) for $\mathrm{C}_{29} \mathrm{H}_{56} \mathrm{~N}_{8} \mathrm{Zn}_{4} \mathrm{Br}_{4}(1098.06 \mathrm{~g} / \mathrm{mol}): \mathrm{H}, 5.23$ (5.14); C, 31.68 (31.72); N, 9.88 (10.20). ${ }^{1} \mathrm{H}$ NMR (300 $\left.\mathrm{MHz}, \mathrm{C}_{6} \mathrm{D}_{6}, 25{ }^{\circ} \mathrm{C}\right): \delta 1.28\left(\mathrm{~d}, 24 \mathrm{H},{ }^{3} J_{H H}=6.2 \mathrm{~Hz}, \mathrm{CH}\left(\mathrm{CH}_{3}\right)_{2}\right), 1.56\left(\mathrm{~d}, 24 \mathrm{H},{ }^{3} J_{H H}=6.2 \mathrm{~Hz}\right.$, $\left.\mathrm{CH}\left(\mathrm{CH}_{3}\right)_{2}\right), 3.78$ (sept, $\left.4 \mathrm{H},{ }^{3} J_{H H}=6.2 \mathrm{~Hz}, \mathrm{CH}\left(\mathrm{CH}_{3}\right)_{2}\right), 4.20$ (sept, $\left.4 \mathrm{H},{ }^{3} J_{H H}=6.2 \mathrm{~Hz}, \mathrm{CH}\left(\mathrm{CH}_{3}\right)_{2}\right) .{ }^{13} \mathrm{C}$ NMR (200 MHz, $\left.\mathrm{C}_{6} \mathrm{D}_{6}, 25{ }^{\circ} \mathrm{C}\right): \delta 23.7\left(\mathrm{CH}\left(\mathrm{CH}_{3}\right)_{2}\right), 24.8\left(\mathrm{CH}\left(\mathrm{CH}_{3}\right)_{2}\right), 49.0\left(\mathrm{CH}\left(\mathrm{CH}_{3}\right)_{2}\right), 51.0$ $\left(\mathrm{CH}\left(\mathrm{CH}_{3}\right)_{2}\right), 72.8\left(\mathrm{CC}_{4}\right), 169.9(\mathrm{NCN})$. ATR-IR: $v$ 2966, 2930, 2873, 1553, 1510, 1453, 1389, 1364, $1307,1253,1239,1125,1107,1060,1011,932,897,868,658,522,447 \mathrm{~cm}^{-1}$.

$\left\{\mathbf{C}\left[\mathbf{C}(\mathbf{N i}-\mathbf{P r})_{2} \mathbf{Z n I}\right]_{4}\right\}$, 4. $0.25 \mathrm{~g}$ of $\mathbf{1}(0.3 \mathrm{mmol})$ and $0.54 \mathrm{~g}$ of $\mathrm{AlI}_{3}(1.3 \mathrm{mmol})$ were dissolved in 15 $\mathrm{mL}$ of diethylether and stirred for $4 \mathrm{~h}$ at $40{ }^{\circ} \mathrm{C}$. Thereafter, all volatiles were removed at reduced pressure, and the resulting yellowish solid was dissolved in $15 \mathrm{~mL}$ of toluene, filtrated through a frit and stored at $-30{ }^{\circ} \mathrm{C}$ for crystallization. Colorless crystals of 4 were formed within $12 \mathrm{~h}$ and isolated by filtration.

Yield (isolated crystals): $0.22 \mathrm{~g}(58 \%)$. Melting point: $223{ }^{\circ} \mathrm{C}$ (decomposition). Anal. Found (calcd) for $\mathrm{C}_{29} \mathrm{H}_{56} \mathrm{~N}_{8} \mathrm{Zn}_{4} \mathrm{I}_{4}(1286.07 \mathrm{~g} / \mathrm{mol}): \mathrm{H}, 4.30$ (4.39); C, 27.04 (27.08); N, 8.47 (8.71). ${ }^{13} \mathrm{C}$ CP MAS NMR (400 MHz, $\left.25^{\circ} \mathrm{C}\right): \delta 23.8\left(\mathrm{br}, \mathrm{CH}\left(\mathrm{CH}_{3}\right)_{2}\right), 49.7$ (br, $\left.\mathrm{CH}\left(\mathrm{CH}_{3}\right)_{2}\right), 73.0\left(\mathrm{CC}_{4}\right), 169.8(\mathrm{NCN})$. ATR-IR: $v$ $2962,2930,2873,1588,1549,1510,1456,1392,1371,1257,1235,1068,1011,864,793,700,661$, $522,450 \mathrm{~cm}^{-1}$.

$\left\{\mathbf{C}\left[\mathbf{C}(\mathbf{N i} \text {-Pr })_{2} \mathbf{Z n R}\right]_{4}\right\} .1 \mathrm{mmol} \mathrm{RLi}(\mathrm{R}=\mathrm{Me}, n-\mathrm{Bu})$ was added dropwise to a solution of $0.23 \mathrm{~g}$ of 2 $(0.25 \mathrm{mmol})$ in $15 \mathrm{~mL}$ of toluene at $-78{ }^{\circ} \mathrm{C}$. The resulting solution was slowly warmed to ambient temperature and stirred for additional $2 \mathrm{~h}$. Thereafter, all volatiles were removed at reduced pressure and the resulting yellowish solid was dissolved in $15 \mathrm{~mL}$ of hexane, filtrated and the filtrate dried in vacuum, yielding $\mathbf{1 a}$ and $\mathbf{5}$ as colorless solids. 
\{C[C(Ni-Pr)2ZnMe]4\} 1a. Yield: $0.17 \mathrm{~g}(74 \%)$.

$\left\{\mathbf{C}\left[\mathbf{C}(\mathbf{N i}-\mathbf{P r})_{2} \mathbf{Z n}(\boldsymbol{n}-\mathbf{B u})\right]_{4}\right\}$ 5. Yield: $0.20 \mathrm{~g}(81 \%)$. Melting point: $250{ }^{\circ} \mathrm{C}$ (decomposition). Anal. Found (calcd) for $\mathrm{C}_{45} \mathrm{H}_{92} \mathrm{~N}_{8} \mathrm{Zn}_{4}(1006.91 \mathrm{~g} / \mathrm{mol})$ : H, 9.04 (9.21); C, 53.27 (53.68); N, 11.01 (11.13). ${ }^{1} \mathrm{H}$ NMR $\left(300 \mathrm{MHz}, \mathrm{C}_{7} \mathrm{D}_{8}, 0{ }^{\circ} \mathrm{C}\right): \delta 0.60\left(\mathrm{~m}, 8 \mathrm{H}, \mathrm{CH}_{2} \mathrm{CH}_{2} \mathrm{CH}_{2} \mathrm{CH}_{3}\right), 1.12\left(\mathrm{~d}, 24 \mathrm{H},{ }^{3} J_{H H}=6.4 \mathrm{~Hz}\right.$, $\left.\mathrm{CH}\left(\mathrm{CH}_{3}\right)_{2}\right), 1.15\left(\mathrm{t}, 12 \mathrm{H},{ }^{3} J_{H H}=7.3 \mathrm{~Hz}, \mathrm{CH}_{2} \mathrm{CH}_{2} \mathrm{CH}_{2} \mathrm{CH}_{3}\right), 1.20\left(\mathrm{~d}, 24 \mathrm{H},{ }^{3} J_{H H}=6.4 \mathrm{~Hz}, \mathrm{CH}\left(\mathrm{CH}_{3}\right)_{2}\right)$, $1.64\left(\mathrm{~m}, 8 \mathrm{H}, \mathrm{CH}_{2} \mathrm{CH}_{2} \mathrm{CH}_{2} \mathrm{CH}_{3}\right), 1.86\left(\mathrm{~m}, 8 \mathrm{H}, \mathrm{CH}_{2} \mathrm{CH}_{2} \mathrm{CH}_{2} \mathrm{CH}_{3}\right), 3.72$ (sept, $4 \mathrm{H},{ }^{3} J_{H H}=6.4 \mathrm{~Hz}$, $\left.\mathrm{CH}\left(\mathrm{CH}_{3}\right)_{2}\right), 4.15$ (sept, $\left.4 \mathrm{H},{ }^{3} J_{H H}=6.4 \mathrm{~Hz}, \mathrm{CH}\left(\mathrm{CH}_{3}\right)_{2}\right) \cdot{ }^{13} \mathrm{C} \mathrm{NMR}\left(200 \mathrm{MHz}, \mathrm{C}_{7} \mathrm{D}_{8}, 25{ }^{\circ} \mathrm{C}\right): \delta 14.2$

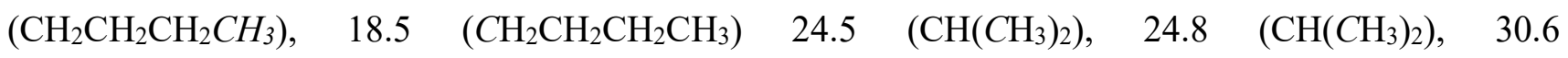
$\left(\mathrm{CH}_{2} \mathrm{CH}_{2} \mathrm{CH}_{2} \mathrm{CH}_{3}\right), 32.0\left(\mathrm{CH}_{2} \mathrm{CH}_{2} \mathrm{CH}_{2} \mathrm{CH}_{3}\right), 47.0\left(\mathrm{CH}\left(\mathrm{CH}_{3}\right)_{2}\right), 48.8\left(\mathrm{CH}\left(\mathrm{CH}_{3}\right)_{2}\right), 71.9\left(\mathrm{CC}_{4}\right), 169.9$ $(\mathrm{NCN})$. ATR-IR: v 2953, 2917, 2900, 2867, 2803, 1549, 1510, 1451, 1385, 1363, 1254, 1077, 1013, $949,830,788,691,669,578,472 \mathrm{~cm}^{-1}$.

$\left\{\mathbf{C}\left[\mathbf{C}(\mathbf{N i}-\mathbf{P r})_{2} \mathbf{Z n E t}\right]_{4}\right\}$ 6. $0.22 \mathrm{~g} \mathrm{EtBr}(2 \mathrm{mmol})$ was added to a dispersion of $0.05 \mathrm{~g} \mathrm{Mg}(2 \mathrm{mmol})$ in 15 $\mathrm{mL}$ of THF. After refluxing this mixture for $2 \mathrm{~h}$ a solution of $0.25 \mathrm{~g}$ of $2(0.27 \mathrm{mmol})$ in $15 \mathrm{~mL}$ of THF was added at room temperature. The resulting suspension was heated to $40{ }^{\circ} \mathrm{C}$ for $2 \mathrm{~h}$. All volatiles were removed at reduced pressure and the resulting yellowish solid was dissolved in $15 \mathrm{~mL}$ of hexane, filtrated and the filtrate dried in vacuum. 6 was obtained as colorless crystalline solid.

Yield (isolated crystals): $0.19 \mathrm{~g}(79 \%)$. Melting point: $250{ }^{\circ} \mathrm{C}$ (decomposition). Anal. Found (calcd) for $\mathrm{C}_{37} \mathrm{H}_{76} \mathrm{~N}_{8} \mathrm{Zn}_{4}(894.69 \mathrm{~g} / \mathrm{mol})$ : $\mathrm{H}, 8.49$ (8.56); C, 49.47 (49.67); N, 12.38 (12.52). ${ }^{1} \mathrm{H}$ NMR (300 $\left.\mathrm{MHz}, \mathrm{C}_{7} \mathrm{D}_{8},-10^{\circ} \mathrm{C}\right): \delta 0.64\left(\mathrm{q}, 8 \mathrm{H}, \mathrm{CH}_{2} \mathrm{CH}_{3}\right), 1.14\left(\mathrm{~d}, 24 \mathrm{H},{ }^{3} J_{H H}=6.4 \mathrm{~Hz}, \mathrm{CH}\left(\mathrm{CH}_{3}\right)_{2}\right), 1.25(\mathrm{~d}, 24 \mathrm{H}$, $\left.{ }^{3} J_{H H}=6.4 \mathrm{~Hz}, \mathrm{CH}\left(\mathrm{CH}_{3}\right)_{2}\right), 1.66\left(\mathrm{t}, 12 \mathrm{H}, \mathrm{CH}_{2} \mathrm{CH}_{3}\right), 3.76$ (sept, $\left.4 \mathrm{H},{ }^{3} J_{H H}=6.4 \mathrm{~Hz}, \mathrm{CH}\left(\mathrm{CH}_{3}\right)_{2}\right), 4.21$ (sept, $\left.4 \mathrm{H},{ }^{3} J_{H H}=6.4 \mathrm{~Hz}, \mathrm{CH}\left(\mathrm{CH}_{3}\right)_{2}\right) .{ }^{13} \mathrm{C} \mathrm{NMR}\left(200 \mathrm{MHz}, \mathrm{C}_{7} \mathrm{D}_{8}, 25{ }^{\circ} \mathrm{C}\right): 9.3\left(\mathrm{CH}_{2} \mathrm{CH}_{3}\right), \delta 13.3$ $\left(\mathrm{CH}_{2} \mathrm{CH}_{3}\right), 24.4\left(\mathrm{CH}\left(\mathrm{CH}_{3}\right)_{2}\right), 24.8\left(\mathrm{CH}\left(\mathrm{CH}_{3}\right)_{2}\right), 46.9\left(\mathrm{CH}\left(\mathrm{CH}_{3}\right)_{2}\right), 48.7\left(\mathrm{CH}_{\left.\left(\mathrm{CH}_{3}\right)_{2}\right),}\right), 8\left(\mathrm{CC}_{4}\right), 169.9$ (NCN). ATR-IR: v 2961, 2903, 2852, 1554, 1508, 1446, 1411, 1256, 1082, 1008, 896, 868, 783, 690, $659,605,512 \mathrm{~cm}^{-1}$.

Single crystal X-ray analyses of 2,3 , and 4 . A suitable crystal was covered in mineral oil, mounted on a glass fiber and then transferred to the Bruker AXS SMART APEX CCD diffractometer. 
Crystallographic data for $\mathbf{2}$ - $\mathbf{4}$ are summarized in Table 2. Figures 2 shows an ORTEP diagram of the solid-state structure of $\mathbf{2}$. The structures were solved by Direct Methods (SHELXS-97) ${ }^{18}$ and refined by full-matrix least-squares on $\mathrm{F}^{2}$. Semi-empirical absorption corrections were applied. All non-hydrogen atoms were refined anisotropically and hydrogen atoms by a riding model (SHELXL-97, Program for Crystal Structure Refinement) ${ }^{19}$ on idealized geometries with the 1.2 fold (1.5 fold for methyl groups) isotropic displacement parameters of the equivalent Uij of the corresponding carbon atom. The absolute structures of 2 - 4 were determined (Flack parameter $0.016(9) \mathbf{2}, 0.027(11) \mathbf{3}, 0.052(19)$ 4). ${ }^{20}$ The elemental cells of $\mathbf{2}-\mathbf{4}$ each contain three additional toluene molecules disordered over two sites with SOF 0.5, which were refined with isotropic displacement parameters hydrogen atoms.

The crystallographic data of $\mathbf{2}$ - 4 (excluding structure factors) have been deposited with the Cambridge Crystallographic Data Centre as supplementary publication nos. CCDC-761556 (2), CCDC761557 (3), CCDC-761558 (4). Copies of the data can be obtained free of charge on application to CCDC, 12 Union Road, Cambridge, CB21EZ (fax: (+44) 1223/336033; e-mail: deposit@ccdc.camak.uk)

Acknowledgment. S. Schulz thanks the German Science Foundation (DFG) for generous financial support. We also like to thank M. Zähres, University of Duisburg-Essen, for recording the ${ }^{13} \mathrm{C}$ CPMAS spectra.

Supporting Information Available. Tables, text, thermal ellipsoid plots, and a CIF file giving X-ray crystallographic data of $\mathbf{2}, \mathbf{3}$, and $\mathbf{4}$ as well as tables of absolute energies and NBO analyses of $\mathbf{2}^{\mathbf{\prime}}-\mathbf{5}^{\prime}$. This material is available free of charge via the Internet at http://pubs.acs.org. 


\section{Figure / Scheme Captions}

Figure 1. ${ }^{13} \mathrm{C}$ CPMAS spectra of 2 (red) and 4 (blue). Resonances at 120 and 220 ppm are rotation sidebands of the $\mathrm{CN}_{2}$ resonance.

Figure 2. Solid state structure of $\mathbf{2}$ (thermal ellipsoids are shown at 50\% probability levels); $\mathrm{H}$ atoms are omitted for clarity.

Figure 3. Temperature-dependent ${ }^{1} \mathrm{H}$ NMR spectra of $\mathbf{6}$ showing the region with the characteristic septets of the non-equivalent $i$-Pr groups and their coalescence around $64{ }^{\circ} \mathrm{C}$. 
Figure 1

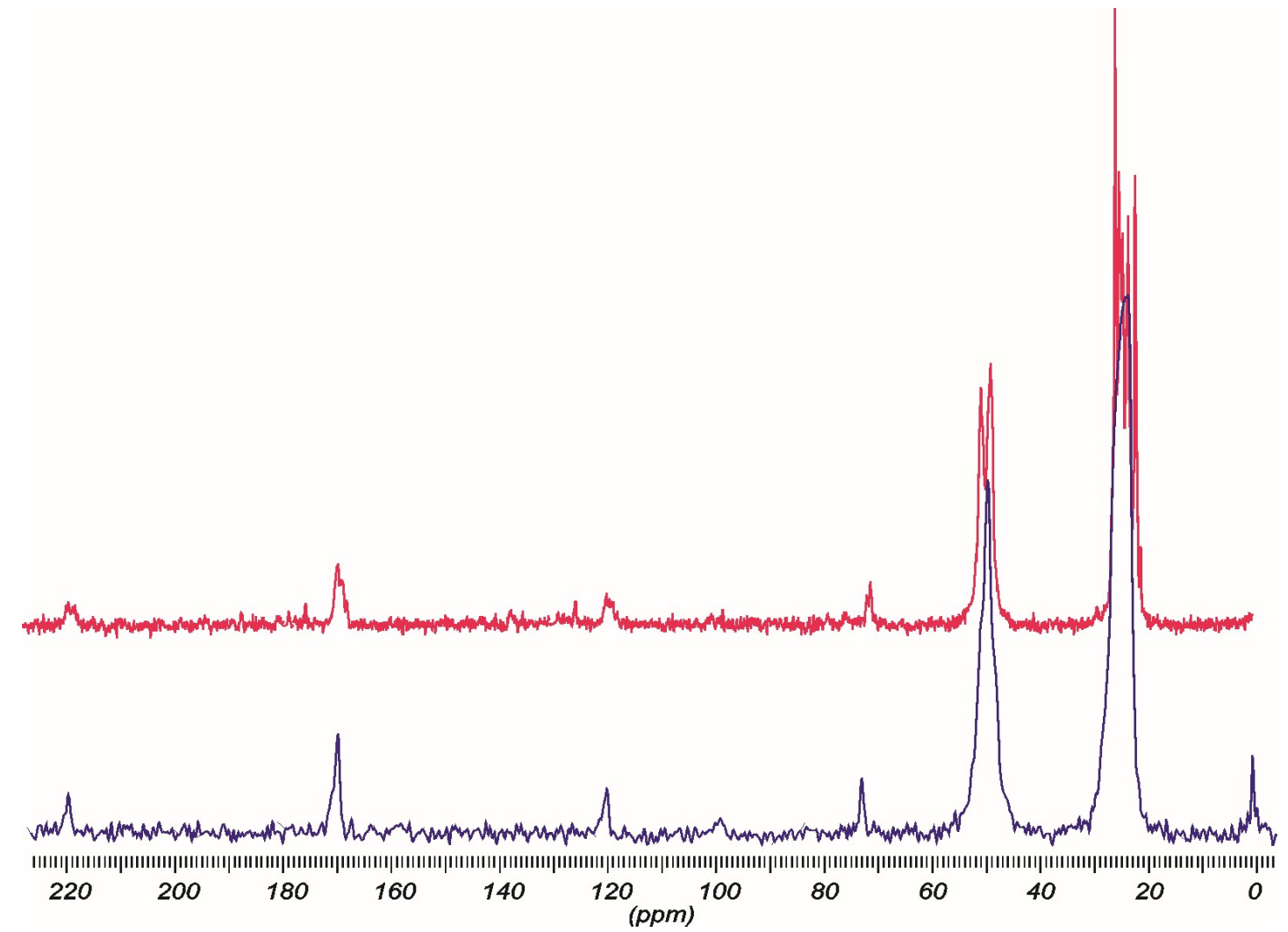


Figure 2

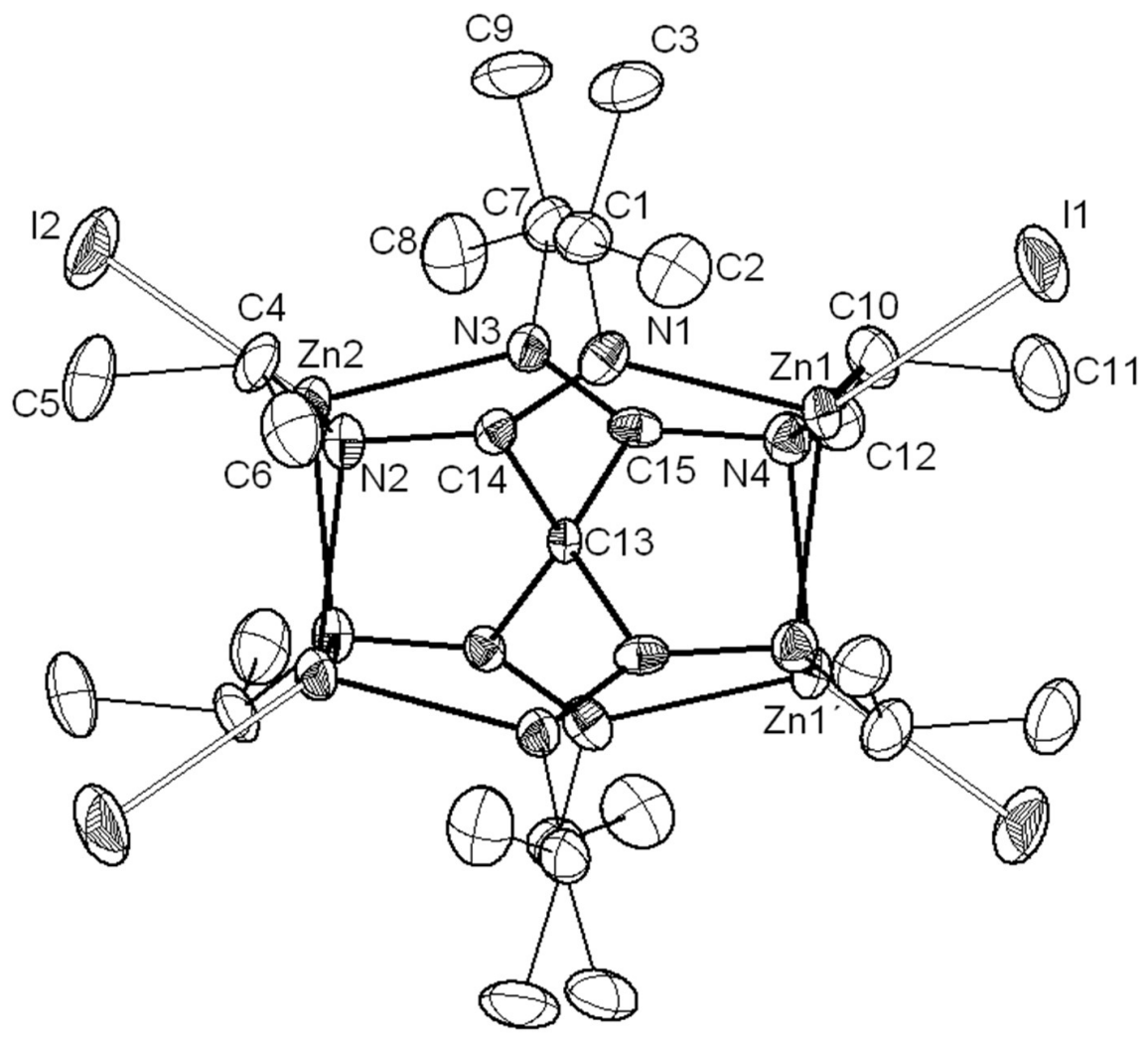

13

Accepted Manuscript 
Figure 3

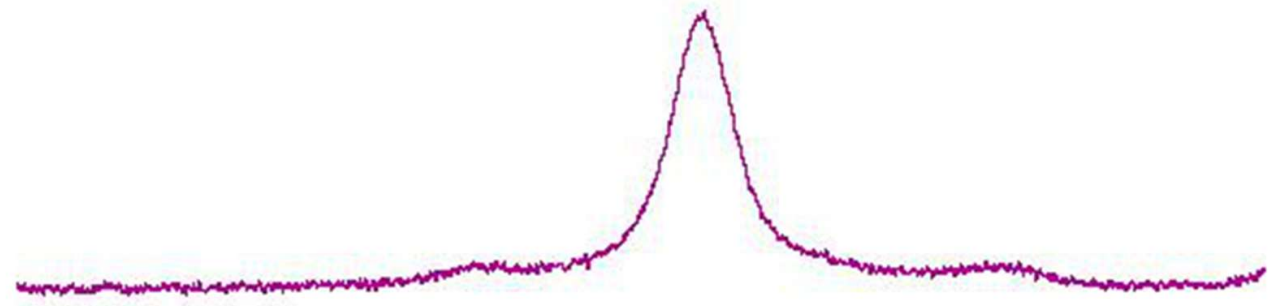

$373 \mathrm{~K}$

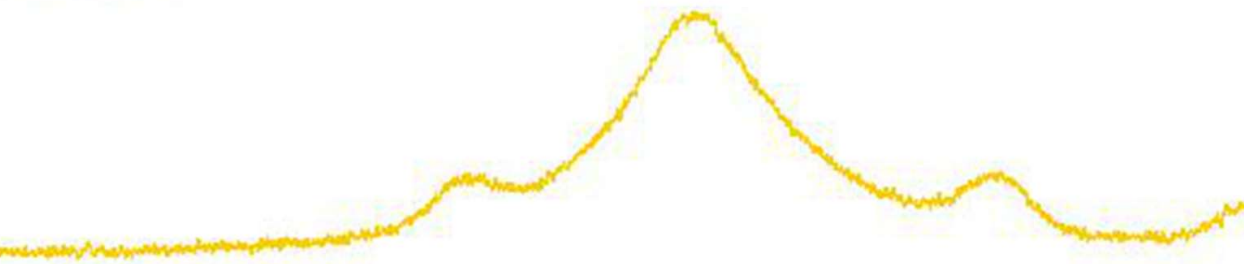

$353 \mathrm{~K}$

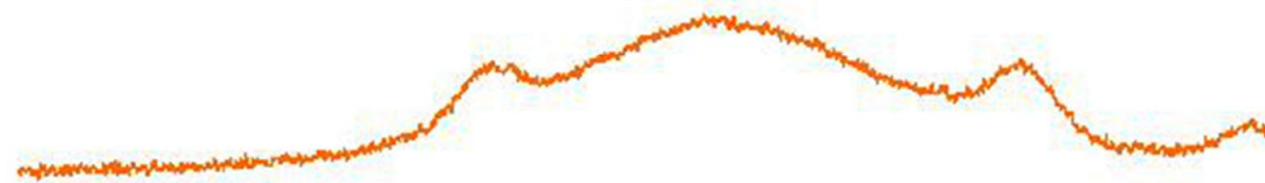

$343 \mathrm{~K}$

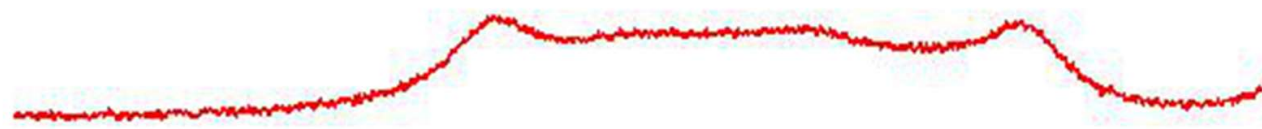

$338 \mathrm{~K}$

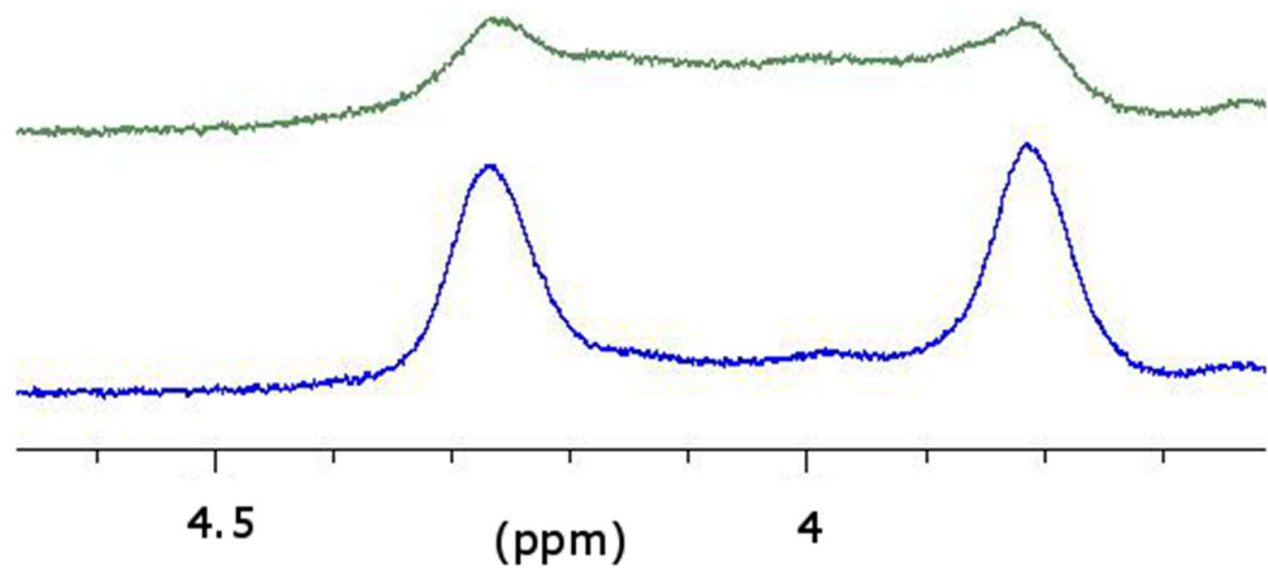

$333 \mathrm{~K}$

$313 \mathrm{~K}$ 


\section{SCHEME TITLES}

Scheme 1. Multinuclear metal amidinate complexes.

Scheme 2. Syntheses of $2-4$ by methyl/halide exchange reaction between 1 a and $\mathrm{AlX}_{3} ; \mathrm{N}$-bonded $i$-Pr substituents are omitted for clarity.

Scheme 3. Syntheses of 1a, 5 and $\mathbf{6}$ by salt metathesis reaction using either organolithium or Grignard reagents; N-bonded $i$-Pr substituents are omitted for clarity.

Scheme 4. Equilibrium between the "open-type" and "cage-type" forms of the cluster complexes $\mathbf{5}$ and 6. 
TABLES.

Table 1: ${ }^{13} \mathrm{C}$ CPMAS resonances of $\mathbf{2}$ and $\mathbf{4}$

\begin{tabular}{|c|c|c|c|c|}
\hline & $i$-Pr $(\mathrm{Me})$ & $i$-Pr $(\mathrm{CH})$ & $C \mathrm{C}_{4}$ & $\mathrm{CN}_{2}$ \\
\hline$\left\{\mathrm{C}\left[\mathrm{C}(\mathrm{N} i-\mathrm{Pr})_{2} \mathrm{ZnCl}\right]_{4}\right\} \mathbf{2}$ & $22.3-26.0$ & $49.0 ; 50.8$ & 71.2 & 169.8 \\
\hline$\left\{\mathrm{C}\left[\mathrm{C}(\mathrm{N} i-\mathrm{Pr})_{2} \mathrm{ZnI}\right]_{4}\right\} \mathbf{4}$ & 23.8 & 49.7 & 73.0 & 169.8 \\
\hline
\end{tabular}


Table 2. Crystallographic details of 2, 3, and 4 .

\begin{tabular}{|c|c|c|c|}
\hline & 2 & 3 & 4 \\
\hline Empirical formula & $\begin{array}{l}\mathrm{C}_{29} \mathrm{H}_{56} \mathrm{~N}_{8} \mathrm{Cl}_{4} \mathrm{Zn}_{4} * \\
3\left[\mathrm{C}_{7} \mathrm{H}_{8}\right]\end{array}$ & $\begin{array}{l}\mathrm{C}_{29} \mathrm{H}_{56} \mathrm{~N}_{8} \mathrm{Br}_{4} \mathrm{Zn}_{4} * \\
3\left[\mathrm{C}_{7} \mathrm{H}_{8}\right]\end{array}$ & $\begin{array}{l}\mathrm{C}_{29} \mathrm{H}_{56} \mathrm{~N}_{8} \mathrm{I}_{4} \mathrm{Zn}_{4} * \\
3\left[\mathrm{C}_{7} \mathrm{H}_{8}\right]\end{array}$ \\
\hline Molecular mass & 1176.43 Da & 1366.28 & 1554.24 \\
\hline Crystal system & trigonal & trigonal & trigonal \\
\hline Space group & $\mathrm{P} 3{ }_{1} 21$ & $\mathrm{P} 3{ }_{1} 21$ & $\mathrm{P} 3{ }_{2} 21$ \\
\hline $\mathrm{a}=\mathrm{b}[\AA]$ & $11.844(1)$ & $11.969(1)$ & $12.208(1)$ \\
\hline $\mathrm{c}[\AA]$ & $34.425(2)$ & $34.481(2)$ & $34.722(3)$ \\
\hline $\mathrm{V}\left[\AA^{3}\right]$ & $4182.0(4)$ & $4277.9(3)$ & $4481.5(6)$ \\
\hline$Z$ & 3 & 3 & 3 \\
\hline $\mathrm{T}[\mathrm{K}]$ & $173(1)$ & $173(1)$ & $173(1)$ \\
\hline $\operatorname{Radiation}(\lambda[\AA])$ & Mo-K $\alpha(0.71073)$ & Mo-K $\alpha(0.71073)$ & Mo-K $\alpha(0.71073)$ \\
\hline$\mu\left[\mathrm{mm}^{-1}\right]$ & 1.931 & 4.503 & 3.691 \\
\hline $\mathrm{D}_{\text {calcd. }}\left[\mathrm{g} \mathrm{cm}^{-3}\right]$ & 1.401 & 1.591 & 1.728 \\
\hline $2 \theta_{\max }\left[{ }^{\circ}\right]$ & 55 & 55 & 55 \\
\hline Crystal dim. [mm] & $0.22 \times 0.15 \times 0.08$ & $0.17 \times 0.12 \times 0.03$ & $0.32 \times 0.27 \times 0.18$ \\
\hline No. of reflections & 29037 & 51793 & 50374 \\
\hline No. of unique reflections & 6257 & 6433 & 6838 \\
\hline$R_{\text {merg }}$ & 0.0242 & 0.0513 & 0.0212 \\
\hline No. param. refined / restraints & $288 / 0$ & $284 / 0$ & $283 / 0$ \\
\hline$R 1^{[\mathrm{a}]}$ & 0.0294 & 0.0351 & 0.0346 \\
\hline$w R 2^{[\mathrm{b}]}$ & 0.0756 & 0.0781 & 0.0730 \\
\hline Goodness of fit ${ }^{[\mathrm{c}]}$ & 1.087 & 1.017 & 1.291 \\
\hline Final max/min. $\Delta \rho$, e $\AA^{-3}$ & $1.355 /-0.314$ & $0.578 /-0.421$ & $0.821 /-0.574$ \\
\hline
\end{tabular}

\footnotetext{
${ }^{[\mathrm{a}]} R 1=\Sigma\left(|| F_{\mathrm{o}}|-| F_{\mathrm{c}}||\right) / \Sigma\left|F_{\mathrm{o}}\right|($ for I $>2 \sigma(\mathrm{I})) .{ }^{[\mathrm{b}]} w R 2=\left\{\Sigma\left[w\left(F_{\mathrm{o}}{ }^{2}-F_{\mathrm{c}}{ }^{2}\right)^{2}\right] / \Sigma\left[w\left(F_{\mathrm{o}}{ }^{2}\right)^{2}\right]\right\}^{1 / 2} .{ }^{[\mathrm{c}]}$ Goodness of fit
} $=\left\{\Sigma\left[w\left(\left|F_{\mathrm{o}}{ }^{2}\right|-\left|\mathrm{F}_{\mathrm{c}}{ }^{2}\right|\right)^{2}\right] /\left(\mathrm{N}_{\text {observns }}-\mathrm{N}_{\text {params }}\right)\right\}^{1 / 2}$. 
Table 3. Calculated natural charges of $\left\{\mathrm{C}\left[\mathrm{C}(\mathrm{N} i-\mathrm{Pr})_{2} \mathrm{ZnX}\right]_{4}\right\}\left(\mathrm{X}=\mathrm{F} 5^{\prime}, \mathrm{Cl} 2^{\prime}, \mathrm{Br} 3^{\prime}, \mathrm{I}^{\prime}\right)$.

\begin{tabular}{c|ccccc} 
& $\mathrm{Zn}$ & $\varnothing\left(\mathrm{N}_{\mathrm{a}}\right)$ & $\varnothing\left(\mathrm{N}_{\mathrm{b}}\right)$ & $\mathrm{X}$ & $\mathrm{C} 1$ \\
\hline $\mathbf{5}^{\prime}$ & 1.33 & -0.94 & -0.77 & -0.74 & -0.19 \\
$\mathbf{2}^{\prime}$ & 1.11 & -0.93 & -0.76 & -0.54 & -0.19 \\
$\mathbf{3}^{\prime}$ & 1.09 & -0.92 & -0.77 & -0.52 & -0.18 \\
$\mathbf{4}^{\prime}$ & 0.97 & -0.93 & -0.76 & -0.40 & -0.18 \\
$\mathrm{~N}_{\mathrm{a}}=\mathrm{N} 2, \mathrm{~N} 2^{\prime}, \mathrm{N} 4, \mathrm{~N}^{\prime} ; \mathrm{N}_{\mathrm{b}}=\mathrm{N} 1, \mathrm{~N}^{\prime}, \mathrm{N} 3, \mathrm{~N} 3^{\prime}$ & &
\end{tabular}

Table 4. Selected bond lengths $[\AA]$ and angles $\left[{ }^{\circ}\right]$ of $\mathbf{2}-\mathbf{4}$ and calculated complexes $\mathbf{2}^{\prime}-\mathbf{5}^{\prime}$ '

\begin{tabular}{llllllll}
\hline & $\mathbf{5}^{\prime}$ & $\mathbf{2}$ & $\mathbf{2}^{\prime}$ & $\mathbf{3}$ & $\mathbf{3}^{\prime}$ & $\mathbf{4}$ & $\mathbf{4}^{\prime}$ \\
\hline Ø(C-N) & 1.350 & 1.332 & 1.3533 & 1.3328 & 1.354 & 1.330 & 1.356 \\
C13-C14 & 1.580 & $1.563(3)$ & 1.5824 & $1.563(4)$ & 1.582 & $1.589(5)$ & 1.581 \\
C13-C15 & 1.582 & $1.569(3)$ & 1.5839 & $1.565(4)$ & 1.583 & $1.567(5)$ & 1.583 \\
Zn1-N1 & 2.108 & $2.093(2)$ & 2.1224 & $2.090(3)$ & 2.128 & $2.104(4)$ & 2.148 \\
Zn1-N4 & 2.140 & $2.105(2)$ & 2.1462 & $2.114(3)$ & 2.165 & $2.114(4)$ & 2.141 \\
Zn1-N4' & 2.128 & $2.142(2)$ & 2.1203 & $2.145(3)$ & 2.145 & $2.157(4)$ & 2.183 \\
Zn2-N2 & 2.106 & $2.110(2)$ & 2.1575 & $2.113(3)$ & 2.155 & $2.106(4)$ & 2.136 \\
Zn2-N3 & 2.144 & $2.098(2)$ & 2.1180 & $2.094(3)$ & 2.129 & $2.099(4)$ & 2.147 \\
Zn2-N2' & 2.126 & $2.144(2)$ & 2.1348 & $2.143(3)$ & 2.131 & $2.148(3)$ & 2.163 \\
Ø(Zn-X) & 1.838 & 2.172 & 2.238 & 2.307 & 2.371 & 2.503 & 2.571 \\
C14-C13-C15 & 99.6 & $101.7(1)$ & 99.4 & $101.7(2)$ & 99.4 & $101.4(2)$ & 99.3 \\
C14-C13-C14' & 131.3 & $130.2(3)$ & 131.2 & $130.4(4)$ & 130.9 & $130.1(5)$ & 130.9 \\
C14-C13-C15 & 100.0 & $98.9(1)$ & 100.3 & $99.0(2)$ & 100.4 & $99.1(2)$ & 100.8 \\
C15-C13-C15' & 131.3 & $129.9(3)$ & 131.2 & $129.4(4)$ & 131.0 & $130.1(5)$ & 130.8 \\
N1-C14-N2 & 137.2 & $136.8(2)$ & 136.9 & $136.7(4)$ & 136.7 & $138.6(4)$ & 136.4 \\
N3-C15-N4 & 137.2 & $136.8(2)$ & 136.8 & $136.7(4)$ & 136.7 & $136.9(4)$ & 136.5
\end{tabular}




\section{References}

[1] L. Bourget-Merle, M. F. Lappert, J. R. Severn, Chem. Rev. 2002, 102, 3031-3065.

[2] M. P. Coles, Dalton Trans. 2006, 985-1001.

[3] F. T. Edelmann, Adv. Organomet. Chem. 2008, 57, 133-352.

[4] J. Barker, M. Kilner, Coord. Chem. Rev. 1994, 133, 219-300.

[5] P. C. Junk, M. L. Cole, Chem. Commun. 2007, 1579-1590.

[6] L. Zhang, M. Nishiura, M. Yuki, Y. Luo, Z. Hou, Angew. Chem. 2008, 120, 2682-2685; Angew. Chem. Int. Ed. 2008, 47, 2642-2645.

[7] F. T. Edelmann, Chem. Soc. Rev. 2009, 38, 2253-2268.

[8] C.-L. Pan, W. Chen, S. Song, H. Zhang, X. Li, Inorg. Chem. 2009, 48, 6344-6346.

[9] H. E. Abdou, A. A. Mohamed, J. P. Fackler, J. Cluster Science 2007, 18, 630-641.

[10] X. Jiang, J. C. Bollinger, M.-H. Baik, D. Lee, Chem. Commun. 2005, 1043-1045.

[11] U. Riaz, O. J. Curnow, M. D. Curtis, J. Am. Chem. Soc. 1994, 116, 4357-4363.

[12] R. A. Fischer, Chem. Unserer Zeit 1995, 29, 141-152.

[13] H. Beinert, R. H. Holm, E. Münck, Science 1997, 227, 653-659.

[14] M. Münch, F. Flörke, M. Bolte, S. Schulz, D. Gudat, Angew. Chem. 2008, 120, 1535-1537; Angew. Chem. Int. Ed. 2008, 47, 1512-1514.

[15] S. Schmidt, S. Gondzik, S. Schulz, D. Bläser, R. Boese, Organometallics 2009, 28, 4371-4376.

[16] 1a failed to react with water at ambient temperature, whereas decomposition reactions occurred at elevated temperatures $\left(>70{ }^{\circ} \mathrm{C}\right)$. 
[17] The ${ }^{13} \mathrm{C}$ CPMAS NMR spectrum of 2 corresponds very well to the ${ }^{13} \mathrm{C}$ NMR spectrum of 2 recorded in solution.

[18] G. M. Sheldrick, Acta Crystallogr. Sect. A 1990, 46, 467.

[19] G. M. Sheldrick, Program for Crystal structure Refinement; Universität Göttingen, 1997.

[20] H. D. Flack, Acta Cryst. 1983, A39, 876-881. 
Table of Contents (TOC)

Halide-substituted complexes $\left\{\mathrm{C}\left[\mathrm{C}(\mathrm{N} i-\mathrm{Pr})_{2} \mathrm{ZnX}\right]_{4}\right\} \quad[\mathrm{X}=\mathrm{Cl} \mathbf{2}, \mathrm{Br} \mathbf{3}, \mathrm{I}$ 4] were obtained from methyl/halide exchange reactions between $\left\{\mathrm{C}\left[\mathrm{C}(\mathrm{N} i-\mathrm{Pr})_{2} \mathrm{ZnMe}\right]_{4}\right\}$ 1a and $\mathrm{AlX}{ }_{3}$. Salt elimination reactions of 2 with organolithium and magnesium reagents yielded $\left\{\mathrm{C}\left[\mathrm{C}(\mathrm{N} i-\mathrm{Pr})_{2} \mathrm{ZnR}\right]_{4}\right\}(\mathrm{R}=\mathrm{Me} \mathbf{1 a}, n$ $\mathrm{Bu}$ 5, Et 6).

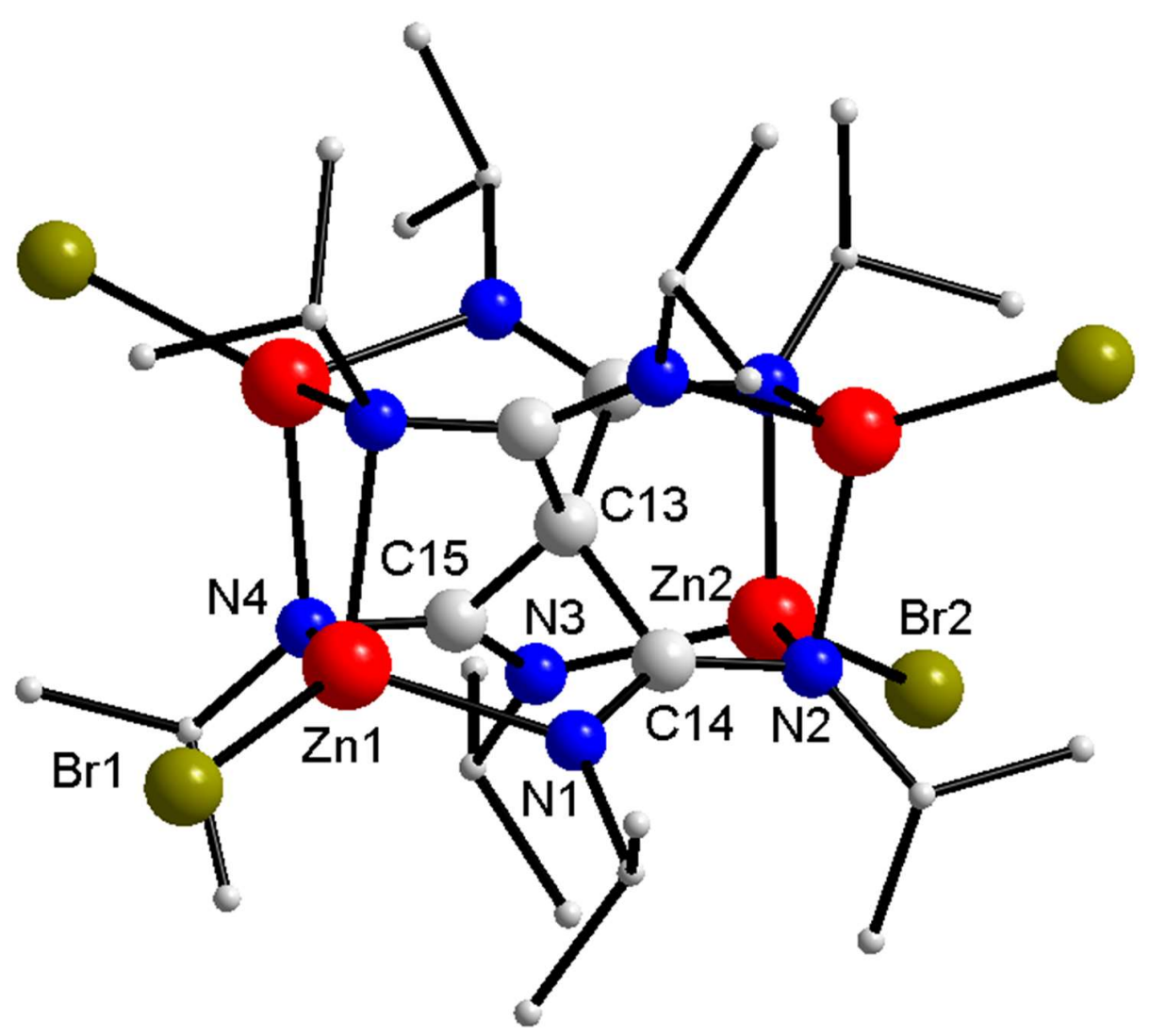




\section{DuEPublico}

Duisburg-Essen Publications online
DESTEBN R G

offen im Denken

$\mathbf{U b} \mid \begin{gathered}\text { universitäts } \\ \text { bibliothek }\end{gathered}$

This text is made available via DuEPublico, the institutional repository of the University of Duisburg-Essen. This version may eventually differ from another version distributed by a commercial publisher.

DOI: $\quad 10.1021 / \mathrm{om} 100065 \mathrm{w}$

URN: urn:nbn:de:hbz:464-20201104-073058-1

This document is the Accepted Manuscript version of a Published Work that appeared in final form in: Organometallics 2010, 29, 9, 2093-2097, copyright (C) American Chemical Society after peer review and technical editing by the publisher.

To access the final edited and published work see: https://doi.org/10.1021/om100065w

All rights reserved. 